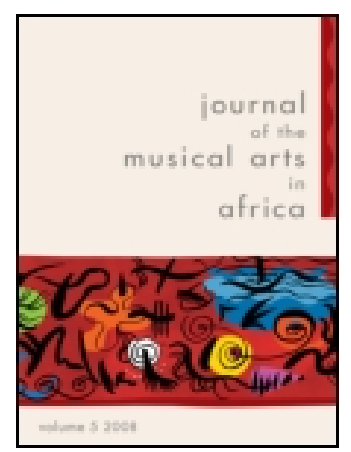

Journal of the Musical Arts in Africa

\title{
The first scholarly South African interpretation of Wagner? Ramsden Balmforth's Fabian analysis of the Ring and Parsifal
}

\section{Frederick Hale}

To cite this article: Frederick Hale (2013) The first scholarly South African interpretation of Wagner? Ramsden Balmforth's Fabian analysis of the Ring and Parsifal, Journal of the Musical Arts in Africa, 10:1, 53-69

To link to this article: http://dx.doi.org/10.2989/18121004.2013.846981

$$
\text { Published online: } 20 \text { Dec } 2013 .
$$

Submit your article to this journal ¿

Џ Article views: 25

Q View related articles ¿ 


\title{
The first scholarly South African interpretation of Wagner? Ramsden Balmforth's Fabian analysis of the Ring and Parsifal
}

\author{
Frederick Hale
}

North-West University (Potchefstroom campus), South Africa

email:fh243@cam.ac.uk

\begin{abstract}
2013 marks both the bicentenary of Richard Wagner's birth and the centenary of performances of his Ring cycle in Cape Town, which contemporary critics hailed as a noteworthy advance in the cultural life of the Mother City. In that year the first South African to write a book about Wagner, the transplanted Yorkshireman Ramsden Balmforth, crafted his Drama, Music-drama, and Religion. It is argued in the present article that his interpretation relied to an appreciable degree on George Bernard Shaw's 1898 The Perfect Wagnerite, but also incorporated Balmforth's own Fabian socialist and post-orthodox Christian notions which he perceived in both the Ring cycle and Parsifal. Balmforth's interpretation further reflected the influence of his many years in South Africa, where he served as a Unitarian minister and engaged indefatigably in social reform efforts, which generally meshed with the ideological precepts he had brought from England. To a significantly greater extent than Shaw he delved into individual traits of Wagnerian characters rather than perceiving them almost exclusively as manifestations of social classes.
\end{abstract}

\section{Introduction}

The year 2013 marks not only the bicentenary of Richard Wagner's birth but also the centenary of the publication of the first book about him by a South African. The confluence of these events provides a particularly fitting stimulus to examine how Ramsden Balmforth (1861-1941), a Capetonian from Yorkshire, interpreted what he regarded as the essential Wagnerian message. He perceived Wagner refracted through a prism of his own ideological convictions, national prejudices, religious views and aesthetic sensitivities. I shall argue that Balmforth, especially in his 1913 work Drama, Music-drama, and Religion (subtitled As Illustrated by Wagner's 'Ring of the Nibelung' and 'Parsifal') incorporated an amalgam of late Victorian and Edwardian perspectives drawn chiefly from post-orthodox theological modernism, Fabian socialism and George Bernard Shaw's The Perfect Wagnerite to develop his unique understanding of Wagner's works. Despite its significance, Drama, Music-drama, 
and Religion has apparently been almost entirely overlooked in Wagner scholarship, a situation the present article seeks to redress. Balmforth's volume will be contextualised with reference to earlier British treatments of Wagner's works and, no less significantly, the much-heralded performance of the Ring cycle in Cape Town by the touring Quinlan Opera Company, which took place as the lectures that form part of the core of the book were being delivered only a few hundred metres away.

Although Balmforth never completely shed his British identity, he immersed himself in South African public life before the end of the nineteenth century and remained very active in it almost until his death (Hale 2012). Beginning shortly after he arrived in Cape Town in 1897 to occupy the pulpit of its Free Protestant Church (which would later call itself 'Unitarian'), a position he would hold with only brief respites for four decades, this Christian socialist from Yorkshire wore many hats. In addition to his ministry in Hout Street (the core of which was his preaching on Sunday evenings), he wrote more than a dozen books about theological and literary topics, and contributed articles to the daily and religious press as well as scholarly journals in South Africa, the United Kingdom and the United States of America. Balmforth also served on various civic committees and played an active part in such organisations as the South African Peace and Reconciliation Society and the Cape Fabian Society. For his efforts, he gained considerable recognition in his second homeland as well as the country of his birth. Editor John Cope of the liberal Johannesburg weekly review The Forum optimistically assured readers in 1942 that 'Ramsden Balmforth will long be remembered in Cape Town and, indeed, in South Africa, as a pioneer of progressive thought' (Cope 1942:5). Moreover, this uprooted English socialist retained his membership in the British Fabian Society, which he joined in 1890, until the year of his death (Donnelly 2012). His ideological commitment would strongly influence his understanding of Wagner, as will be seen below, especially with regard to such matters as the allegedly allegorical content of the Ring.

Balmforth had a keen interest in imaginative literature and edited series of lectures about novels and dramatic works as books. In accordance with both his agape-ist understanding of Christianity as essentially a matter of living according to the moral teachings of Jesus (and, by extension, reforming society in harmony therewith), and his conviction that significant human ethical progress is possible, he held no brief for the classical tenet ars gratia artis ('art for art's sake'), at least as far as drama was concerned. Instead, to this Fabian socialist it was virtually axiomatic that works for the theatre were driven by purpose, and that especially in the modern era they existed in large measure to serve various reform movements. As such, he asserted, they had great potential. Indeed, this seasoned preacher who elsewhere evinced great enthusiasm for educational endeavours could assert in The Ethical and Religious Value of the Drama that 'the best drama [...] may be of more effective service for good than either theology or pedagogy'. The theatre, in other words, existed not merely as a venue for entertainment; it had instrumental value, especially for effecting social and political change. Balmforth informed readers how he thought drama played this role: 'Like great poetry, it is not only a criticism and an interpretation of life: it gives us also gleams and visions of what 
life might be and ought to be' (Balmforth 1925:5). As we shall see below, this conviction clearly underlay his interpretation of Wagner.

In his willingness to comment on recent music, Balmforth stood squarely in a specific tradition of British Christianity. Men of the cloth had done so - often quite critically - for centuries. To cite but one relatively well-known precedent, in the 1780s John Newton, the erstwhile slave trader who had undergone a conversion experience and become an Anglican divine in London, penned a series of 50 sermons which took their point of departure in Handel's Messiah. He lamented that many contemporary Englishmen had elected 'to make the solemnities of their impending trial, the character of their judge, and the awful sentence to which they are exposed, the ground-work of a musical entertainment' (Mackerness 1964:116). What is significantly different about Balmforth's interpretation of Wagner is that as a post-Protestant theological liberal he was willing to extract lessons from a series of musical works which he found dovetailed neatly with his social and political views.

\section{The 1913 Wagner Centenary in South Africa}

Balmforth's volume was by no means the sole South African contribution to the Wagner centenary. In Johannesburg, Cape Town and elsewhere concerts commemorated the occasion. On the eve of the Meister's birthday in May 1913, for example, Johannesburgers attended a 'Wagner Festival', i.e. a special concert at St Mary's Cathedral in the heart of that city. As reviewed in the Rand Daily Mail, the performance featured the band of the Tenth Royal Hussars, whose playing was 'exceedingly fine', vocalists and pieces played on the church's organ. Selections from Tannhäuser, Parsifal and other operas highlighted the programme (Rand Daily Mail 1913:8). E J Osborne, the editor of The South African Musical Times, published his own tripartite article of several thousand words and titled simply 'Wagner' in the May, June and July issues (O[sborne] 1913:6-8, 6-8, 7-8, respectively). Though providing a solid general overview of its subject, this piece was not intended to break new scholarly ground.

In terms of artistic achievement, the high-water mark may have been reached when the talent-laden but short-lived Quinlan Opera Company from London included Cape Town on its intercontinental tour in June 1913. It was not the first visit to the Mother City by this international (though largely British) assembly of approximately 160 artistes. In collaboration with the Cape Town Amateur Operatic and Dramatic Society and its leader, the actor and impresario Leonard Rayne, which until 1912 had concentrated its efforts much more on Gilbert and Sullivan productions than on grand opera, it had performed in Cape Town for a fortnight in February and March the previous year. At that time its Irish-English director, Thomas Quinlan, had promised to return in 1913 (Cape Argus 1912a:6). As the music critic of The Cape Argus, writing under the pseudonym 'Bohemian', observed just before the 1912 series, 'Years have passed since a grand opera company was in Cape Town, so that the present enterprise is certain to receive a cordial welcome' (Bohemian 1912:3). Indeed, 
reviews of its productions of inter alia Wagner's Tristan and Isolde and Tannhäuser, Puccini's Madame Butterfly and La Bohème, Bizet's Carmen and Offenbach's Tales of Hoffmann (all sung in English) in the Cape Times and The Cape Argus were generally enthusiastic. After attending the performance of Die Walküre at the end of February, the critic from the Argus professed that Cape Town had not previously experienced a 'rendering' of Die Walküre of its calibre (Cape Argus 1912b:7). After a few weeks in Johannesburg, the Quinlan Opera Company returned to Cape Town for three final performances billed as a 'Great Musical Festival' in the City Hall before embarking for Australia (Quinlan Opera Company Souvenir n.d.). At a reception for Quinlan, Rayne underscored 'the great boon' the visit by his 'great company' had brought to the advancement of opera in South Africa (Cape Argus 1912a:6).

Quinlan's troupe honoured his promise and returned some fifteen months later, this time with a repertoire of which the Ring cycle formed the nucleus of its repertoire. Critics spared few words in praising the four performances (Cape Times 1913a:8, Cape Times 1913b:8, Cape Times 1913c:8, Cape Times 1913d:10). A few weeks before the company landed in Cape Town, the theatre and music critic at The Cape Argus declared that the production of Wagner's four-part Lebenswerk would be 'the greatest event which the musical community have ever been asked to support' and an 'epoch-making event' (Bohemian 1913a:3). Quinlan and his 172 musicians and other personnel arrived from London on 7 June 1913, shortly after completing a tour of the United Kingdom (Cape Argus 1913b:7). That evening he and a small number of his company were fêted at a reception held in the Minor Hall of the City Hall. Among the dozens of dignitaries present were the Mayor of Cape Town, Harry Hands and German Consul-General von Humboldt (Cape Argus 1913d:7).

In both 1912 and 1913 the Quinlan performances of Wagnerian and other operas were performed in Cape Town's centrally located Opera House, a structure which had been erected in 1893 and used for various kinds of musical and dramatic events. This is clear from dozens of contemporaneous reviews and advertisements in the Cape Times and The Cape Argus. Such prima facie evidence contradicts the assertion in Jacques P Malan's extensive but often unreliable South African Music Encyclopedia that 'only one opera was ever staged in the Opera House: Tannhäuser by Wagner' (Malan 1986:332).

\section{Non-socialist Victorian interpretations of the Ring}

Well before 1913 a variety of interpretations of Wagner's Musikdramen, to use the composer's preferred term, had emerged in continental Europe and the Anglophone world, especially the United Kingdom and the United States of America. The preceding 40 years had stimulated critical thinking about the man, his compositions and, to a lesser degree, his prose. Not only in continental Europe but also in the United Kingdom Wagner's reputation was established well before his demise in 1883. In 1872, for example, the English Wagner Society was founded; it would subsequently publish a journal called The Meister. This society, it should be noted, was established when Balmforth was not 
yet a teenager in Yorkshire and antedated his departure for Cape Town by fifteen years. To cite but one other early non-German manifestation of significant interest outside Germany, Revue wagnérienne was founded in Paris in 1885 and chiefly published analyses and exaltations of Wagner's works. On British shores a spate of late Victorian books about him were issued, such as Nicholas Kilburn's The Story of Wagner's 'Ring' for English Readers and Freda Winworth's The Epic of Sounds: An Elementary Interpretation of Wagner's Nibelungen Ring, and David Irvine's more specifically thematic but detailed 'Parsifal' and Wagner's Christianity. From 1895 younger readers had Constance Maud's Wagner's Heroes. For American aficionados, Henry T Finck's Wagner and His Works. The Story of His Life with Critical Comments was repeatedly republished after its initial appearance in 1893.

Exceeding these early works in their scope and influence, Ernest Newman's irregular series of biographies and other studies of Wagner began to appear shortly before 1900. This partly self-taught scholar and journalist, who would eventually serve as the music critic of The Sunday Times, placed himself at the forefront of British commentators with such works as $A$ Study of Wagner (1899), Wagner (1904), and Wagner as Man and Artist (1914). Furthermore, in the 1890s William Ashton Ellis translated and published in eight volumes much of Wagner's copious prose. This seminal accomplishment made accessible to Anglophone readers much of the composer's often controversial thought about music, religion, ethnicity, politics, nationalism and the ostensible incompatibility of Judaism and Germanentum.

Prior to the publication of Shaw's The Perfect Wagnerite in 1898, British commentators had published a variety of interpretations of the Ring cycle and other Wagnerian operas, generally from non-socialist perspectives. In these analyses, commentators had often concentrated on individual moral characteristics and personal traits of the personae against the backdrop of the mythical structures which Wagner had employed. They had dissected the works in question and highlighted inter alia what they perceived as his exploration of how various human and divine characters' infringements of moral law inevitably had dire consequences. Quite typical was Winworth's popular The Epic of Sounds, which was published initially in London in 1897 and almost immediately thereafter in Philadelphia. To avoid any misunderstanding of her non-ideological and non-sociological perspective, she included a schematised prefatory synopsis in which one reads, for example, that Wotan exemplifies 'fear engendered by the lust of power', while Alberich embodies 'the temptation to become tyrannical, which the possession of power offers' and Siegfried 'the incompatibility of the desire for fame with love' (Winworth 1897:xxviii).

By no means were all pre-Shavian Victorian interpretations secular. Noteworthy were the very lengthy (and misleadingly entitled) 'lectures' - 'Richard Wagner and Pessimism' and 'Wagner's Parsifal' - by the Scottish Congregationalist Peter Taylor Forsyth, which he included in his volume of 1889, Religion in Recent Art. Being Expository Lectures on Rossetti, Burne-Jones, Watts, Holman Hunt, and Wagner (Forsyth 1889:235-284, 285-301). That Wagner was a singular genius with a cornucopia of artistic and intellectual gifts this minister did not doubt. Writing six years after the Meister had died, Forsyth was gratified that the British public were belatedly beginning to comprehend that in music he must stand among the masters and 
immortals', but lamented that few of his compatriots in the United Kingdom knew anything about the man's stature as a writer of dramas or understood that he had 'revolutionised opera'. Even without composing a note, Forsyth averred, Wagner would 'have taken a permanent place among dramatists of the stamp represented by Schiller'. Reflecting his own interests and perspective, he generalised that the British were innocent of 'the vast religious thoughts underlying his creative work or of the religious mission which finally came to dominate his amazing activity'. But, oddly enough for an increasingly prominent clergyman who was becoming known as a defender of theological orthodoxy against the inroads of modernism, Forsyth hailed his artistic hero as 'the most gifted and passionate expositor of that semireligious philosophy and semi-Christian atheism which is associated with the names of Schopenhauer and Pessimism' (Forsyth 1889:236-237). Understood as a nineteenth-century philosophy stemming chiefly from Arthur Schopenhauer (and popularised in the Englishspeaking world especially through the translated works of Karl Robert Eduard von Hartman), pessimism professed that the world as we know it is deeply flawed, indeed so bad that it could not become significantly worse without becoming essentially chaotic. This was the opposite of Leibniz's eighteenth-century optimistic notion of the 'best of all possible worlds'. Calling music the 'religion' of pessimism and Wagner its 'prophet', Forsyth quoted Wagner's comment on the Ring cycle which was a near-echo of Schopenhauer's worst of all possible worlds Weltanschauung: 'In this conception I had unwittingly uttered the truth as to human affairs. All here is tragic from first to last. And the will which sets to fashion a world according to its wish can attain at the close nothing more satisfactory than a catastrophe of honourable ruin' (Forsyth 1889:239-240).

Forsyth was equally effusive in his praise of Wagner's final Musikdrama, Parsifal, assuring readers that nowhere in his works could one find a more impressive amalgam 'of imposing spectacle, of pure poetry, of philosophic thought, of imaginative passion, of solemn religion, and a dramatic action and characterisation, full of pity, terror, truth, and grandeur.' Pulling out even more stops, this Congregationalist minister asserted that 'nothing like Parsifal, on the whole, has been seen, either in art of religion, since the Greek tragedians awed and melted Athens by lyric dramas which were at the same time religions functions.' The principal theme of this capstone of Wagner's career, he declared, was 'Redemption' in an 'ideal' rather than historic form (Forsyth 1889:285-286).

\section{Shaw's Ground-breaking The Perfect Wagnerite}

In 1898 the Irish-born English dramatist and Fabian socialist George Bernard Shaw published his The Perfect Wagnerite. A Commentary on the Ring of the Niblungs [sic]. Eschewing all modesty, he unabashedly declared his ability - which he apparently regarded as virtually unique in the United Kingdom - to interpret Wagner correctly. Earlier British and American commentators, he averred, were 'gentlemen-amateurs', almost invariably 'political mugwumps', who had simply not been in a position to appreciate how Wagner's revolutionary ideas from the late 1840 s had shaped the ideological content of the Ring 
cycle. His sole objective in filling what he perceived as a glaring lacuna in the relevant scholarship was 'to impart the ideas which are most likely to be lacking in the conventional Englishman's equipment' (Shaw 1905:vi). In a passage dripping with self-assurance and condescension, Shaw announced that 'there is an inner ring of superior persons to whom the whole work has a most urgent and searching philosophic and social significance' and that he was 'such a superior person' (Shaw 1905:2). In full accordance with this attitude, though without identifying any authors or titles, after launching his leftist political interpretation of Wagner, Shaw peremptorily took to task readers who might object thereto. He declared that 'some foolish person is sure to interrupt us by declaring that The Rhine Gold is what they call 'a work of art' pure and simple, and that Wagner never dreamt of shareholders, tall hats, whitelead factories, and industrial and political questions looked at from the socialistic and humanitarian points of view' (Shaw 1905:33). Instead of arguing with his unseen opponents, Shaw devoted the fourth of his fourteen chapters, 'Wagner as a Revolutionist', to that young, democratically-minded composer's participation in the revolutionary events of the late 1840s, concentrating on the insurrection in the Saxon capital, Dresden, i.e. only a few years before working on Das Rheingold during his Swiss exile. Anyone who dismissed his interpretation of that work as merely a function of Shaw's socialism, he professed, 'may safely be dismissed from your consideration as an ignoramus' (Shaw 1905:36).

A detailed recapitulation of The Perfect Wagnerite lies outside the scope of the present article. Rather, we shall focus on a small number of footsteps which Shaw made in the snow of Wagnerian scholarship and in which Balmforth uncritically and, in places, avowedly, followed.

Given his certitude that Das Rheingold and the other three works of the Ring cycle were artistic expressions of Wagner's mid-nineteenth-century revolutionary spirit, it is hardly surprising that Shaw could argue that to a great extent they were allegorical opéras à thèse. Indeed, in a preliminary summary, he postulated it as self-evident that 'of course, the dwarfs, giants, and gods [in the Ring cycle] are dramatizations of the three main orders of men: to-wit, the instinctive, predatory, lustful people; the patient, toiling, stupid, respectful, money-worshipping people; and the intellectual, moral, talented people who devise and administer States and Churches.' Yet this Fabian believed there was one stratum of humanity 'higher' than these three castes, namely 'the order of Heroes'. They, he believed, would lead the wholesale reform of society which he believed was essential and inevitable. Shaw thought that 'if the next generation of Englishmen consisted wholly of Julius Caesars, all our political, ecclesiastical, and moral institutions would vanish', assigned to the 'dustbin of History along with Stonehenge'. It was a vision which subsequently led him to praise, albeit not permanently, such dynamic iconoclasts as Mussolini and Stalin. Such a category of men, he averred, would sally forth unfettered by such 'contrivances as our codes and churches'. They would be no more restrained by the straitjacket of conventionality than 'a Fellow of the Royal Society will touch his hat to the squire and listen to the village curate's sermons.' Much of 'our barbarous Theology and Law', Shaw predicted, would simply disappear under such heroic leadership (Shaw 1905:38-39). 
Siegfried symbolised Shaw's vision of such an iconoclastic hero emerging from outside the bounds of conventional society and how, raised in the absence of fear, subservience, religion and social convention, he could boldly use the weapons at his disposal to slay dragons. In the second edition of The Perfect Wagnerite (which Balmforth may have read in Cape Town), Shaw described Siegfried as a youth who 'knows no law but his own humor' and 'a totally unmoral person, a born anarchist, the ideal of Bakoonin, an anticipation of the "overman" of Nietzsche'. Especially with Siegfried in mind, he compared the Ring cycle to Shelley's Prometheus Unbound ('an English attempt at a Ring'), asserting that the young English poet had anticipated Wagner already in 1819. Shaw acknowledged significant differences between the two works but emphasised thematic parallels: 'Both works set forth the same conflict between humanity and its gods and government, issuing in the redemption of man from their tyranny by the growth of his will into perfect strength and self-confidence; and both finish by a lapse into panacea-mongering didacticism by the holding up of Love as the remedy for all evils and the solvent of all social difficulties' (Shaw 1910:48, 72).

\section{Balmforth's Wagnerian lectures}

Less than a fortnight before the Quinlan Opera Company disembarked in Cape Town to observe the Wagner centenary, Balmforth launched a series of lectures on Sunday evenings from the pulpit of the Free Protestant Church, also known as the Unitarian Church, in Hout Street. He had served that congregation since arriving in the Cape in 1897. Much of this transplanted Englishman's ministry was intellectually inclined and meshed with his writing of books in which he expounded on social issues and promoted theological liberalism, which tended to blur the conventional distinctions between the religious and secular realms, and emphasised Christian ethics while downplaying doctrinal orthodoxy. Particularly germane to a consideration of Balmforth's dissection of Wagner's operas, especially the Ring cycle, is an awareness of his commitment to evolutionary socialism. From 1891 until his death in 1941 he belonged to the Fabian Society, which Shaw and like-minded social reformers had founded in 1884 and whose goals centred on inter alia the elimination of the British social class system. Neither Balmforth's religious thought nor his literary and musical criticism can be understood apart from that preoccupation. It influenced his perception and interpretation of Wagner's operas.

Balmforth's rhetorical endeavour was an unvarnished exploitation of the extensive publicity surrounding the Wagner centenary and the forthcoming opera season. That Balmforth delivered a cluster of talks which rotated around a theme was by no means out of character. Rather than preaching on the texts of a fixed lectionary, for example, he frequently did such series for his well-educated congregation about extra-biblical themes. In this case, Balmforth announced that he would speak about 'the Ring of the Nibelungs [sic]'. As reported in the daily press the following day, in his initial lecture he decried what he regarded as a 'Philistine' modern tendency to divorce drama generally from religion, even though many defenders of such separation inconsistently conceded that religious 
sentiment was 'the inspirer of the best in the allied arts of music and painting'. Illustrating the point, this devotee of the contemporary theatre explained that Stephen Phillips had to set his biblically-themed drama, The Sin of David, which had been published in 1904 in the United Kingdom but premiered in Johannesburg earlier in 1913 and played a week earlier in Cape Town, in seventeenth-century England (Cape Argus 1913a:5). The enthusiastic reception Phillips's work had received in both cities may have emboldened Balmforth and convinced him that his conviction that drama and religious motifs could still co-exist symbiotically had been vindicated (Bohemian 1913b:3, Cape Argus 1913c:7).

In a sequel delivered on 8 June, Balmforth generalised that 'all true art' had a religious foundation of one kind or another, a fusion which he believed could be traced to classical Greek dramatists, 'of whom Wagner is the lineal descendant'. Balmforth's justification for his judgment reflected his presuppositions about the centrality of social ethics to Christianity. Again as reported in The Cape Argus, he argued that 'Wagner's greatest dramas were intentionally and deliberately religious, for he was a great reformer who had set himself the task of lifting the people to a better state by means of the drama.' Having established this tenet, Balmforth reasoned that the second segment of the Ring cycle, Die Walküre, illustrated this verity vividly, because it 'symbolised the power of Love, the power of Law, and lastly the power of the Lie - the elusive fires of superstitions which deterred all but the bravest from the search for the truth which shall set men free' (Cape Argus 1913e:7).

\section{Balmforth's Drama, Music-drama, and Religion: The Ring Cycle}

Edited and apparently expanded, Balmforth's lectures during the Wagnerian festival were published in London later in 1913 under the title Drama, Music-drama, and Religion. As Illustrated by Wagner's 'Ring of the Nibelung' and 'Parsifal'. No separate manuscripts of the discourses delivered in Cape Town have survived and press coverage of them was sketchy. Consequently, this book is by default the principal source of information about how Balmforth interpreted Wagner at this noteworthy early point in the history of opera in South Africa, when the great German was also gaining extensive international attention because of the centenary of his birth.

Balmforth did not hide his creditors under a bushel. In his preface he acknowledged that he was 'greatly indebted' not only to W Ashton Ellis's translations of Wagner's prose works but also to Shaw's 'excellent' The Perfect Wagnerite. With typical understatement, Balmforth stated that on 'one or two points' his own opinions differed from those of his 'fellow-Fabian' and that in his treatment of the Ring cycle his perspective was 'more definitely religious' than that of Shaw (Balmforth 1913:5). Furthermore, as he could not read German, in his preface he acknowledged his reliance on the translations of Wagner's dramatic scripts by Margaret Armour, Frederick Jameson and Sabine Baring-Gould. Consequently, for Wagnerian characters Balmforth used such orthography as 'Alberic' and 'Brynhild', a matter about which there was then much inconsistency in the English-speaking world.

Balmforth's approach was in certain respects similar to what he had employed in 
previous studies of literary topics and would continue to use into the 1920s. In an introductory chapter he laid out his general principles, in this case paying particular attention to his conviction that, although Wagner had probably had not stood closer to any form of conventional Christianity than he himself did, the great composer was nevertheless a religious man in that he believed he could inspire the human spirit to a higher level through his art. In that regard, Balmforth argued, he represented a tradition that could be traced back to classical dramatists. Balmforth then considered each of the four music dramas of the Ring cycle in a separate chapter and concluded his book with a treatment of Parsifal, Wagner's final work which, since its public premiere at the Festspielhaus in Bayreuth in 1882, had received extensive attention (both laudatory and damning) in international Christian circles. In each chapter Balmforth summarised the work under review and related its characters to moral, religious and, to a lesser degree, social and economic questions. His overarching attitude towards both the Ring and Parsifal was favourable. Rarely did he comment negatively on the dramatic content.

To a considerable extent Balmforth explicitly followed Shaw's lead in perceiving the Ring cycle as a social allegory, although he did not simply echo the assertion that the characters represented 'the three main orders of men'. Furthermore, Balmforth went significantly beyond him in other areas of his interpretation. This is manifest in his summary of Das Rheingold, most lucidly in the description of Alberic's subterranean realm: 'The clash and clamour of hammer and anvil is heard as hundreds of dwarfs toil unceasingly to heap treasure for their master. Surely the allegory is becoming plain to us at last.' Balmforth cited Shaw, who had viewed this scene as a representation of the Industrial Revolution, a world not of the mythic past, but 'frightfully modern': 'You can see the process for yourself in every civilised country where millions of people toil in want and disease to heap up wealth for our Alberics, laying up nothing for themselves except sometimes horrible and agonising disease and the certainty of premature death.' Balmforth added, 'That subterranean cavern of Alberic might be a gold mine where the miners within a few years cough their lungs to bits, as long as there is any left to cough, in phthisis and tuberculosis' (Balmforth 1913:29). Furthermore, Balmforth echoed Shaw in seeing the Ring as an artistic manifestation of the revolutionary views he had put forth in the late 1840s and the following decade. The Capetonian noted, 'He wrote numerous pamphlets expounding his philosophic, religious, political, and artistic views, in which he inveighed against capitalism, Mammon-worship, vivisection, commercialism, and "the holy, noble god of five per cent"” (Balmforth 1913:25).

Balmforth emphasised as one of his own Leitmotivs that Wagner was no mere entertainer but created his Gesamtkunstwerke as stimuli to 'regenerate' mankind to live on an intellectually and ethically elevated plane. Again echoing Shaw, he declared that Wagner's 'great panacea for the regeneration of mankind was virtually Shelley's, that is, a deeper love than men yet know controlling all the institutions of the people, or the Folk as he called them, and all the wealth and property in the Folk. Love was to be the great bond of society' (Balmforth 1913:24-25). 
Yet to a significant degree this minister was his own man in his critique of Das Rheingold and approached it in terms of his calling. To the theologically very liberal Balmforth, who did not draw a distinct line of demarcation between the religious and secular realms, it seemed virtually axiomatic that the Ring cycle was inherently religious, in that it dealt with ethics and spirituality; moreover, like himself and other Christian socialists, Wagner had sought to nurture the upliftment of humankind. Balmforth could therefore write that it was bootless to 'go to these music-dramas simply to see in them a fairy story of elves and gods, dwarfs and giants', for they would then yield only 'milk for babes and lazy-minded adults who won't take the trouble to think. Wagner would have us go with the seriousness with which we go to a religious service' (Balmforth 1913:25).

Balmforth was a socialist before he entered the Unitarian ministry; in this respect he differed from such prominent advocates of Christian Socialism as Frederick Denison Maurice. Nevertheless, in his interpretation of Wagner, especially the portrayal of the labourers in the Nibelung realm, one finds an appeal to that dimension of Victorian religious life. He found in the Ring a nearly contemporary parallel to the widely read social reform novels of the eminent Anglican divine Charles Kingsley, especially Alton Locke (1850), which called attention to the exploitation of the British working class in both the clothing trade and the agricultural sector (Balmforth 1913:30).

To a greater extent than Shaw, Balmforth perceived individual human traits rather than almost exclusively social classes allegorised in the characters of Das Rheingold. Alberic, for instance, he believed represented 'Mammon, unredeemed by conscience or by love', while Wotan embodied 'the growing conscience of the world', and Loke 'the subtlety, the shiftiness, the elusiveness, the double-dealing of the world' (Balmforth 1913:27).

Proceeding from Das Rheingold to Die Walküre afforded Balmforth an opportunity to expound on the primacy of love in all human relationships and how it must take precedence over legalism. This fitted his assumptions as a post-orthodox Christian about the role of agape love, or charity, in the New Testament as an advance over the rigid codification of law in the Pentateuch. It also allowed this Fabian to comment as a social reformer on current affairs.

In his synopsis of the plot of Die Walküre, Balmforth focused on the relationship of Brynhild to her father, Wotan, and his wife, Fricka. She embodies the spirit of the Law; she is 'cold, hard, brilliant, [and] emotionless, [and] pushes her claims pitilessly to uphold the sanctity of marriage, even the loveless one between Sieglinda and Hunding.' This segment of Wagner's drama, Balmforth was certain, was about the choice between 'Love or Law!' He is not known to have advocated elsewhere the liberalisation of divorce laws in either the United Kingdom or the Union of South Africa, but his comments about Die Walküre suggest where he stood: 'Alas, how many thousands of unloved wives, how many thousands of unloved husbands, have asked that question! How many thousands of young girls, forced into loveless marriages for money or position, have asked the same!' Balmforth counselled readers who wished to explore this theme to examine George Eliot's The Mill on the Floss and Romola, Ibsen's A Doll's House, and George Meredith's Diana of the 
Crossways (Balmforth 1913:45). To him, it was self-evident that the demands of love must take precedence over those of generalised laws when the two clashed.

Brynhild's subsequent demotion to the ranks of the mere mortals and her plea that Wotan not allow her to become the spouse of an oppressive, unheroic husband allowed Balmforth to present her as a forerunner of contemporary women's liberation and, simultaneously, link this to his socialist concerns: 'Had she been living in the twentieth century,' he speculated,

one might well have imagined her saying: 'If I am to have a "mere man" for my mate, let him not be one of the undermen of the world - not one of those who look upon their wives as kitchen-maids and house-slaves; nor yet one of those braggarts, who boast of their chivalry to their sisters and then pay them half-wages for the work which they have e'en done themselves; nor yet one of the loons who talk of equal rights and yet fear to grant equal rights of citizenship to their wives and sisters - let not one of these come to claim me, for that is not to be borne, but let him rather be one who knows no fear, a dauntless hero, who will regard me as an equal mate with him, so that together, hand in hand, heart to heart, and mind to mind we may face the world to search and work for a wider freedom, and a deeper truth, than the world yet knows.' (Balmforth 1913:48)

The ring of fire which Loke, 'the god of craft and cunning', constructs around Brynhild offered Balmforth a final chance to advocate reforms despite the walls of conservative tradition that surround convention. Again taking his cue explicitly from Shaw, he interpreted the protective fires as 'illusive, a delusion, an appearance, a lie' designed to preserve the status quo. 'They represent the lies of superstition which the reformer has to break down or penetrate so he can bring new truth to the world.' An example from European religious life illustrated the point. 'For nearly a thousand years ecclesiasticism held the intellect of Europe as in a vice by those lying fires of Loke,' he lamented. The Christian establishment insisted, often with the support of civil law, that parents submit their children for baptism and threatened both them and their offspring with eternal damnation if they defied this demand. 'It was the Siegfrieds of the time- John Huss, Giordano Bruno, Julius Vanini, Michael Servetus,' Balmforth recalled with reverent gratitude, 'who, at cost of very real fires and bitter suffering to themselves, broke down that lie of superstition which still lingers in out-of-the-way places of the earth.' As in days of yore, so still in Balmforth's own time, he argued; 'for the power of the Lie is everywhere - the lies of Mammon, which raises its thrones on the lives of men; the lies of society and convention, which consecrate marriages in which there is no love; the lies and pedantries of the Law which Dickens exposes in 'Bleak House'; the lies of militarism which seek profit and glory out of wasted lives and broken hearts' (Balmforth 1913:51).

Balmforth's slightly briefer dissection of Siegfried rested in part on his notion of evolving perceptions of both what is divine and humanity's relationship to divinity. One must bear in mind his awareness that Wagner's gods were not perfect supernatural beings but morally, cognitively and otherwise limited mythic figures who could not rise above Fate. Moreover, 
to Balmforth Wotan was partly a projection of human traits: 'His developing conscience, his hesitations, his ardours, his affections, his presage of change are ours.' As such, this Germanic deity's changeability seemed to be quite in harmony with contemporary thought, not least the philosophy of Henri Bergson. 'It is not without significance that there is a revival of Wagner at a time when Bergson and the philosophy of change are in the ascendant,' Balmforth asserted. 'For Wagner, like Bergson, knew that Life is a continual creation of what is new, the continual travail of spirit and thought, and their ascent on a pathway of deepening or increasing spiritualisation' (Balmforth 1913:62-63).

In analysing the character of the heroic Siegfried and particularly his fearless challenging of the gods, Balmforth drew a partial parallel with Prometheus as described by the Athenian tragedian Aeschylus in the fifth century BC. More than this, however, he drew on his own religious heritage and found in Wagner's hero at least a partial Christ figure and linked this to a neologism in European thought. Siegfried was a 'Superman', Balmforth declared, echoing the popular (and arguably very misleading) English translation of Nietzsche's term Übermensch. ${ }^{1}$ But there were two general Superman models, he thought, namely 'the type foreshadowed by Nietzsche, and the type of Christ'. The former included such militant egoists as Alexander the Great, Julius Caesar and Napoleon, who 'stride to empire over the bodies of thousands of men'. In the latter category the pacificist Balmforth placed men like Oliver Cromwell, George Washington and Garibaldi (despite the military careers of all three), because they 'at least, make their people's freedom and welfare their supreme aim'. Relying, as he frequently did, on W. Ashton Ellis's translation of Wagner's 'Jesus of Nazareth', Balmforth found parallels between Siegfried and the founder of Christianity. 'The root desire and motive of Christ's life, said Wagner, proceeds 'not from the Will-tolive, but from the Will-to-redeem,' and to that 'Will-to-redeem' Wagner set himself both in his political, social and religious philosophy and in his music dramas.' In an unvarnished allusion to John 10:10, Balmforth could argue that like Jesus, above all else Wagner wanted for humanity 'more abundant life' (Balmforth 1913:63).

Balmforth concluded his commentary on the Ring cycle with an interpretation of Götterdämmerung. To readers who were familiar with his religious and social thought, it offered few surprises. Again echoing Shaw, he began by emphasising that the mythic divinities were fallible beings, quite distinct from the perfect and omnipotent deity of Christian thought. Unlike his renowned mentor, however, Balmforth did not allegorise Wotan and others in the Nordic pantheon. To Balmforth, given his evolutionary conception of both mankind and religion, Götterdämmerung portrayed the potential of our species for upward spiritual and moral mobility - despite the acknowledged shortcomings of both Siegfried and Brynhild. They showed, he believed, how humanity could eventually surpass the demi-gods whom they replace. An illustration he offered at the outset of his analysis reflected his racial attitudes after some sixteen years in South Africa. Balmforth, who was a severe critic of the massacre of the "Israelites" at Bulhoek of which government

1 For the awareness of Nietzschean thought in the United Kingdom during Balmforth's intellectually formative years, see Thatcher (1972). 
troops were guilty in the Eastern Cape in 1921, proposed that readers 'take a few weeks' old baby born of cultured and highly developed people. Within the heart and mind of that baby there are great hidden and undeveloped potentialities. Yet those undeveloped potentialities might be as nothing before the brute strength say, of a half-savage Kaffir, who might crush the baby to pulp in the hollow of his hand.' Yet the realisation of human potential was not easy; people must undergo 'a long experience of suffering, trial, and discipline, ere they arrive at a full consciousness and possession of power' (Balmforth 1913:65-66). That, above all else, was the essential message of Götterdämmerung.

Not coincidentally, it was also one which harmonised well with both Balmforth's notion of conceptions of the divine evolving over millennia and his sense of calling to serve as a public prophet who spoke out against social and economic injustice, both in South Africa and the United Kingdom. He lauded Siegfried's courage as exemplary. 'What a lesson is here!' Balmforth exclaimed. 'How many of our public men dare speak their full mind on religious and social questions! How many professional men preserve a discreet silence and follow the conventional ways of use and wont through fear of injuring their prospects! ... Even our national policy is often ordered and motived by fear. Moral cowardice is the canker of our political and social life.' Within the realm of religion, Balmforth urged readers to learn from the use of Nordic mythology 'how the advancing and ascending movement of life brings with it new and higher conceptions of God. The god of the savage will be a magnified savage. The god of the civilised man will have the attributes of civilised humanity.' In his own religious tradition and in others an evolution in the comprehension of divinity was at work:

We see this process of development in all religions, and we see it especially in the Bible. We see the god of the early Israelites, who is pleased with the smell of burnt offerings and who reflects the moral code of the time, developing into the mightier god of the Psalmist and the prophet, before whom 'man's days are as grass' and a thousand years are but as 'a watch in the night', and this again into the holier God of Jesus Christ, who is Infinite Spirit and Infinite Love. (Balmforth 1913:77-78)

\section{Drama, Music-drama, and Religion: Parsifal}

The concluding chapter of Drama, Music-drama, and Religion is devoted to Parsifal as a story of the victory of selfless love over basic instincts. Balmforth acknowledged that there had long been 'some diversity' in critical estimations of Wagner's last work, i.e. that to some commentators it was evidence of artistic decline, while to others it was 'the crown and completion of his work'. Balmforth did not directly take sides in this debate. Instead, he contented himself with considering the piece as a lucid portrayal of the continual conflict within people between 'the higher or divine side of our nature, and the lower or purely sensual, passionate, and selfish side'. To Balmforth, it seemed evident that Wagner understood, 'as every thinking person knows', that these two elements were in tension, and that it was 'the work of art and the drama, by means of symbolic and dramatic 
representations, to bring before us that eternal struggle, to show us the conflict of higher and lower forces, and to point to us the better way'. That in fulfilling this purpose Wagner's final music drama resonated well with him is not surprising, because he insisted that this "underlying motive of "Parsifal" was 'the work of religion also'. He perceived in the changed lives of its title character, Kundry, and other personae evidence that higher forms of love could ultimately emerge victorious (Balmforth 1913:89-90). Balmforth could thus conclude that in Wagner 'the theologian, the artist, and the dramatist meet in one' (Balmforth 1913:92).

Balmforth did not attempt to justify Wagner's notoriously disharmonious personality and moral shortcomings. Well before 1900 it had become a commonplace in both the United Kingdom and other countries to distinguish between that composer's sublime music and the uglier aspects of the man. In British musicology, for example, this distinction remained a kind of Wagnerian Leitmotif in the influential works of Ernest Newman. Precisely what Balmforth's sources of information for Wagner's life were is impossible to ascertain. In any case, he juxtaposed Wagner's 'earnest and eloquent pleadings for a higher social order, a purer and more disinterested love, and a wider appreciation and distribution of the treasures and refining influences of art' and 'his egotism, his vanity, his love of finery and luxury, his unnecessary debts, his selfishness, his relations with women'. Yet to Balmforth this and analogous cases involving discrepancies between lofty ideals and depraved conduct were not merely instances of hypocrisy but probably indicated 'some kink, some want of balance in their nature' which 'distorts their vision, or weakens their will, and makes their actual life at issue with what they would be'. He hoped that memory of Wagner's misdeeds would not impair the potential of his music dramas to stimulate human regeneration. Alluding to Marc Antony's oft-quoted funeral oration in Shakespeare's Julius Caesar, Balmforth thought Wagner's sins and shortcomings would be 'interred with [his] bones' (Balmforth 1913:81-82).

This Oxford alumnus thus cast a broad net in either referring or alluding to figures from the literary, philosophica, and religious history of several European countries, including his homeland. Conspicuously absent from his treatment of Wagner's dramas, however, is even the slightest consideration of their music. Balmforth is not known to have had any theoretical or practical training in that field; accordingly, he prudently employed those tools with which he had considerable familiarity.

\section{Conclusion}

The publication of Balmforth's book was one of many noteworthy events that indicated the growing sophistication of the music scene in Cape Town early in the twentieth century. Others obviously included the visits by the massive Quinlan Opera Company and the founding of the South African College of Music in Cape Town in 1910. Research on the history of opera in South Africa remains a relatively unexplored field in which many more furrows must be ploughed if we are to understand the impact of this art form on the culture 
of the nation. The very fact that Balmforth's book originated in Cape Town underscores the broad international influence of Wagner and the ongoing cultural linkage between that corner of the African continent and both continental Europe and the United Kingdom.

While one would err in calling Drama, Music-drama and Religion a seminal work in either South African or British musicology, both it and the performances which prompted Balmforth's lectures and book merit further scholarly investigation. Above all else, Balmforth's interpretation of both the Ring cycle and Parsifal highlights how critics' antecedent political, social and religious views serve as major determinants on their perceptions of musical performances. No critic approaches a work of art with a tabula rasa. In the case of Balmforth, one sees vividly the hand of George Bernard Shaw's The Perfect Wagnerite and both the author's Fabian politics and post-orthodox liberal theological notions at work in his efforts to relay first to his audience in Cape Town and subsequently to his readers in the United Kingdom and elsewhere the gospel of human upliftment which he unswervingly believed Wagner had sought to preach on the stage of the Festspielhaus in Bayreuth. The ongoing march of Wagner scholarship may never shed a great deal of light on the South African dimensions of the international reception of either the Ring cycle or Parsifal (and it can be noted that Saffle's massive Richard Wagner: A Research and Information Guide reveals nothing about this part of the world). For that matter, one will search such works as Anna Dzamba Sessa's Richard Wagner and the English and Lucy Beckett's Richard Wagner: Parsifal, both of which are indispensable for studies of historical British interpretations, in vain for any mention of Balmforth. Surely his lectures and book merit further scholarly attention.

\section{References}

Balmforth, R (1913). Drama, Music-drama, and Religion. As Illustrated by Wagner's 'Ring of the Nibelung' and 'Parsifal.' London: The Year Book Press.

- (1925). The Ethical and Religious Value of the Drama. London: G. Allen \& Unwin.

Bohemian (1912). 'Stage and show.' Cape Argus, 17 February, 3.

- (1913a). 'Stage and show.' Cape Argus, 3 May, 3.

- (1913b). 'Stage and show.' Cape Argus, 17 May, 3.

Cape Argus (1912a). 'Opera season. An annual event, Mr. Quinlan promises’, 16 February, 6.

- (1912b) ‘The Valkyrie. Mr. Quinlan’s production', 29 February, 7.

- (1913a) 'Drama and religion. Discourse on 'the Ring of the Nibelungs [sic]', 26 May, 5.

- (1913b). 'Wagner festival. Arrival of the Quinlan Co. The director and the repertoire', 7 June, 7.

- (1913c) 'Irving's season. “The Sin of David”, 20 May, 7.

- (1913d) 'Grand opera company. Cape Town's Welcome', 9 June, 7.

- (1913e) 'Opera and religion. Rev. Balmforth on 'The Ring”, 4 June, 7.

(1913a). 'Opera house. The Ring of the Nibelung. 1. Das Rheingold', 11 June, 8.

(1913b) 'Opera house. The Ring of the Nibelung. 2. The Valkyrie', 17 June, 8. 
(1913c). 'Opera house. The Ring of the Nibelung. 3. Siegfried', 19 June, 8.

(1913d). ‘Opera house. The Ring of the Nibelung. Götterdämmerung', 21 June, 10.

Cope, J (1942). 'Intrepid liberal' (Editorial), The Forum, Vol. IV, No. 41 (10 January).

Donnelly, S (2012). Email to Frederick Hale, 17 September.

Forsyth, P T (1889). Religion in Recent Art. Being Expository Lectures on Rossetti, Burne-Jones, Watts, Holman Hunt, and Wagner. Manchester: Abel Heywood \& Son.

Hale, F (2012). 'Public issues perceived from the theological left flank: the social ethics of Ramsden Balmforth in the Union of South Africa.' Studia Historiae Ecclesiasticae, 38(1), 235-251.

Mackerness, E D (1964). A Social History of English Music. London: Routledge and Kegan Paul.

Malan, J P (ed.) (1986). South African Music Encyclopedia, 4. Cape Town: Oxford University Press.

O[sborne], E J O (1913). 'Wagner.' The South African Musical Times, I (2):6-8, (3):6-8, (4):7-8.

Quinlan Opera Company Souvenir of the Cape Town Musical Festival, The (n.d.). National Library of South Africa, Special Collections, AZP.1996-1999.

Rand Daily Mail (1913). 'Wagner Festival. Big Concert at St. Mary's', 22 May, 8.

Shaw, B (1905 [1898]). The Perfect Wagnerite. A Commentary on the Ring of the Niblungs. Chicago and New York: Herbert S. Stone.

- (1910 [1898]). The Perfect Wagnerite: A Commentary on the Niblung's Ring. London: Constable and Company.

Thatcher, D S (1972). Nietzsche in England, 1890-1914: The Growth of a Reputation. Toronto: University of Toronto Press.

Winworth, F (1897). The Epic of Sounds. An Elementary Interpretation of Wagner's Nibelungen Ring. London: Simpkin. 